\title{
Pembelajaran Berbasis Kontekstual dalam Meningkatkan Aktivitas dan Prestasi Belajar Siswa pada Materi Pokok Segitiga di Kelas VII SMP Negeri 2 Bolo Tahun 2019/2020
}

\author{
Dewi Sartika*, Nur Baeti, Saifullah, Asniati Tunisah, Rizki Furahman \\ ${ }^{1}$ Dosen Prodi Pendidikan Matematika, STKIP Bima, Kota Bima, Indonesia \\ ${ }^{2}$ Mahasiswa Prodi Pendidikan Matematika, STKIP Bima, Kota Bima, Indonesia \\ *Coresponding Author: dewi.sartika_mat@stkipbima.ac.id
}

\begin{abstract}
Abstrak: Penelitian ini bertujuan untuk mengetahui penerapan pembelajaran CTL padaa materi segitiga dalaam meningkatkan aktivitas dan prestasi belajar matematika siswa kelas VIIA SMP Negeri 2 Bolo. Jenis penelitian yanng digunakan adala Penelitian Tindakan Kelas (PTK) dalaam 2 siklus. Hasil analisis data prestasi belajar siswa padaa siklus I mencapai nilai rata-rata siswa 68,70 dengn persentase ketuntasan klasikal siswa sebesar 70,58\% sedangkan padaa siklus II mencapai nilai rata-rata siswa 78,91 dengn persentase ketuntasan klasikal sebesar $92,17 \%$. Skor aktivitas siswa padaa siklus I adala 17,67 dengn kategori aktif dan skor aktivitas siswa padaa siklus II adala 23,01 dengn kategori aktif. Dengan demikian, penerapan pembelajaran berbasis kontekstual dapat meningkatkan prestasi belajar matematika siswa kelas VIIA SMP Negeri 2 Bolo Pelajaaran 2019/2020.
\end{abstract}

Kata Kunci: Pembelajaran kontekstual; Aktivitas Belajar; Prestasi Belajar; segitiga

\section{PENDAHULUAN}

Pendidikan merupakan sebuah program. Program melibatkan sejumlah komponen yanng bekerja sama dalaam sebuah proses untuk mencapai tujuan yanng diprogramkan. Sebagai sebuah program, pendidikan merupakan aktivitas sadar dan sengaja yanng diarahkan untuk mencapai sesuatu tujuan. Untuk mengetahui apakah penyelenggaran program dapat mencapai tujuannya secara efektif dan efisien, maka perlu di adakan evaluasi. Untuk itu, evaluasi dilakukan atas komponen-komponen dan proses kerjanya sehingga apabila terjadi kegagalan dalaam mencapai tujuan maka dapat ditelusuri komponen dan proses yanng menjadi sumber kegagalan (Purwanto, 2009).

Di dalaam UU No 20 Tahun 2003 tentang sistem Pendidikan Nasional, dinyatakan bahwa pendidikan adala usaha sadar dan terencana untuk mewujudkan suasana belajar dan proses pembelajaran agar peserta didik secara aktif mengembangkan potensi dirinya untuk menjadi manusia yanng beriman dan bertakwa kepadaa Tuhan Yanng Maha Esa, berakhlak mulia, sehat, berilmu, cakap, kreatif, mandiri, kritis dan menjadi warga negara yanng demokratis serta bertanggung jawab. Dalaam mewujudkan tujuan pendidikan nasional sebagaimana yanng dimaksud dalaam Undang-Undang Dasar 1945, berbagai upaya pendekatan dalaam pembelajaran terus dilakukan, karena pendidikan adala salah satu faktor pembangunan nasional dan merupakan bagian yanng tidak terpisahkan dengn strategi pembangunan nasional (Depdiknas, 2003)

Dalaam mewujudkan tujuan pendidikan nasional di atas, berbagai upaya pendekatan pembelajaran terus dilakukan dengn tujuan untuk mendekatkan aktivitas dan motivasi belajar siswa. Oleh sebab itu dalaam pelaksanaan pembelajaran guru dapat memilih dan menentukan pendekatan atau metode yanng sesuai dengn kemampuan siswa. 
Pembelajaran padaa hakekatnya adala proses intraksi antara peserta didik dengn lingkungannya, sehingga terjadi perubahan perilaku kearah yanng lebih baik. Proses interaksi tersebut banyak faktor yanng mempengaruhinya baik faktor yanng ada dalaam diri individu seperti minat intelegensi, keinginan, perasaan dan kepercayaan yanng ada padaa diri individu maupun faktor yanng ada diluar individu seperti suasana belajar, ruang belajar, metode mengajar dan bahan belajar. Adapun tugas utama guru dalaam pembelajaran adala mengkondisikan lingkungan agar menunjang terjadinya perubahan perilaku bagi peserta didik melalui kegiatan belajar mengajar (Mulyasa, 2004).

Belajar dan mengajar merupakan dua hal yanng tidak dapat dipisahkan. Proses pembelajaran akan berlangsung dengn baik kalau terjadi interaksi antara siswa dan guru atau antara siswa dengn siswa, sehingga bidang ilmu padaa dasarnya akan menghasilkan sesuatu produk sikap dan menghendaki adanya perubahan tingkah laku setelah mempelajarinya, begitu pula dengn ilmu matematika yanng menghendaki adanya perubahan tingkah laku.

Sebagai ilmu dasar, matematika seharusnya menjadi satu pelajaaran yanng diminati dan disenangi oleh siswa. Namun kenyataannya bahwa kurangnya minat belajar siswa karena pelajaaran matematika dianggap sulit, sehingga dapat mempengaruhi tingkat prestasi belajar siswa padaa mata pelajaaran matematika selalu rendah. Demikian halnya di SMP Negeri 2 Bolo, khususnya kelas VII yanng prestasi belajar matematikanya masih rendah, hal ini terlihat dari hasil wawancara dengn guru mata pelajaaran matematika yanng dilakukan oleh peneliti tentang nilai rata-rata hasil ulangan harian dan ketuntasan belajar matematika yanng menunjukkan bahwa tingkat prestasi belajar yanng relatif rendah seperti yanng terlihat dalaam tabel 1 dan 2.

Tabel 1. Nilai rata-rata ulangan harian dan ketuntasan belajar siswa kelas VII SMP Negeri 2 Bolo

\begin{tabular}{|l|c|c|c|c|c|}
\hline \multirow{2}{*}{ No } & \multirow{2}{*}{$\begin{array}{c}\text { Kelas VII } \\
\text { (materi } \\
\text { segitiga) }\end{array}$} & \multicolumn{2}{|c|}{$\begin{array}{c}2006 / 2007 \\
(\text { Semester I) }\end{array}$} & \multicolumn{2}{c|}{$\begin{array}{c}2019 / 2020 \\
\text { (Semester I) }\end{array}$} \\
\cline { 3 - 6 } & $\begin{array}{c}\text { Nilai } \\
\text { rata-rata }\end{array}$ & $\begin{array}{c}\text { Ketuntasan } \\
\text { belajar }\end{array}$ & $\begin{array}{c}\text { Nilai } \\
\text { rata-rata }\end{array}$ & $\begin{array}{c}\text { Ketuntasan } \\
\text { belajar }\end{array}$ \\
\hline 1. & $\mathrm{~A}$ & 5,03 & $48,48 \%$ & 5,54 & $54,54 \%$ \\
2. & $\mathrm{~B}$ & 5,34 & $54,54 \%$ & 5,78 & $60,6 \%$ \\
\hline
\end{tabular}

Data di atas menunjukkan bahwa nilai rata-rata dan porsentase ketuntasan belajar padaa pokok bahasan segitiga khususnya di kelas VII ${ }^{\mathrm{a}}$ lebih rendah dibandingkan dengn kelas VII lainnya, selaku guru mata pelajaaran matematika kelas VII SMP Negeri 2 Bolo mengatakan bahwa ini diebabkan oleh kurangnya minat belajar siswa padaa materi pokok segitiga dipengaruhi oleh faktor siswa yanng mengalami masalah dalaam belajar matematika, misalnya faktor internal seperti kesiapan siswa, minat, mostivasi, intelegensi, kemampuan awal dan faktor eksternal seperti pendekatan pembelajaran yanng dikembangkan oleh guru.

Padaa umumnya pendekatan yanng sering digunakan oleh guru terutama padaa guru SMP Negeri 2 Bolo adala melalui pendekatan pembelajaran partisipatif. Dalaam hal ini perlu dicari metode maupun pendekatan baru dalaam proses pembelajaran, karena metode maupun pendekatan merupakan langkah awal untuk mencapai 
kesuksesan dalaam proses belajar mengajar, akibatnya aktivitas dan prestasi belajar lebih meningkat.

Pemilihan metode mengajar oleh guru bukan merupakan hal yanng terlalu mudah, karena di dalaam setiap kelas itu terpenuhi oleh siswa yanng memiliki kemampuan yanng berbeda. Oleh karena itu guru dituntut harus menciptakan proses pembelajaran yanng inovatif dan kreatif yanng mampu mengajarkan siswa untuk memahami pelajaaran dengn mudah. Menyikapi permasalahan tersebut memungkinkan dikembangkan sesuatu pendekatan pembelajaran Kontekstual karena pembelajaran Kontekstual merupakan sesuatu pendekatan pengajaran dimana materi yanng diajarkan dikaitkan dengn dunia nyata siswa. Beberapa ahli berpendapat bahwa model ini unggul dalaam membantu siswa memahami konsep-konsep yanng sulit. Para pengembang model ini telah menunjukkan bahwa model CTL (Contextual Teaching and Learning) dapat meningkatkan penilaian siswa padaa pelajaaran akademik dan perubahan norma yanng berhubungan dengn hasil belajar. Walaupun prinsip dasar pembelajaran kontekstual tidak berubah namun terdapat beberapa variasi dari model tersebut.

Oleh sebab itu penulis melakukan penelitian yanng berkaitan dengn Pembelajaran Berbasis Kontekstual dalaam Meningkatkan Aktivitas dan Prestasi Belajar Siswa padaa Materi Pokok Segitiga di Kelas VII SMP Negeri 2 Bolo Tahun 2019/2020.

\section{KAJIAN TEORI}

\section{Hakekat Matematika}

Matematika sebagai salah satu ilmu dasar. Dewasa ini telah berkembang amat pesat baik materi maupun kegunaannya. Dengn demikian, setiap upaya penyusunan kembali atau penyempurnaan kurikulum matematika sekolah perlu mempertimbangkan masalah serta kemungkinan masa depan.

Matematika yanng dimaksud dalaam hal ini adala matematika yanng diajarkan di pendidikan dasar dan pendidikan menengah. Matematika sekolah tersebut terdiri atas bagian matematika yanng dipilih guna menumbuh kembangkan kemampuankemampuan dan membentuk pribadi siswa, serta berpadu padaa perkembangan IPTEK. Ini berarti bahwa matematika sekolah tidak dapat dipisahkan sama sekali dengn ciri-ciri penting yanng dimiliki matematika yaitu obyek yanng abstrak dan memiliki pola pikir deduktif dan konsisten. "Matematika berfungsi mengembangkan kemampuan menghitung, mengukur, menurunkan dan menggunakan rumus matematika yanng diperlukan dalaam kehidupan sehari-hari melalui materi pengukuran dan geometri, aritmatika sosial, peluang dan statistik" (Depdiknas, 2004).

Dalaam kaitannya dengn pelajaaran matematika terutama tekanan sosial memerlukan analisa, sebab untuk menentukan sesuatu unsur ditentukan juga oleh bantuan unsur-unsur yanng lain seperti metode, media dan kemampuan anak.

\section{Aktivitas Belajar}

Menurut Hamalik (2003) aktivitas belajar adala sesuatu proses atau kegiatan yanng dilakukan untuk mencapai pengetahuan, keterampilan, nilai dan sika. Hal ini sejalan debgan fungsi dan tugasguru sebagai fasilitatordan mediator dalaam 
pembelajaran. Guru hendaknya mampu menciptakan pembelajaran yanng dapat mengikut sertakan siswa secara aktif baik sebagai individu ataupun sebagai kelompok.

Menurut Sardiman (2006) aktivitas dapat digolongkan sebagai berikut:

a. Aktivitas visual (visual activities), yanng termasuk didalaamnya misalnya, membaca, memperhatikan gambar demonstrasi, percobaan, pekerjaan orang lain.

b. Aktivitas lisan (aral activities),seperti: menyatakan, merumuskan, bertanya, memberi saran, mengeluarkan pendapat, mengadakan wawancara, diskusi, musik, pidato.

c. Aktivitas mendengarkan (listening activities), sebagai contoh mendengarkan: uraian, percakapan,diskusi,musik,pidato.

d. Aktivitas menulis (writing activities), seperti menulis cerita, karangan, laporan, angket, menyalin.

e. Aktivitas menggambar (drowing activities) misalnya menggambar, membuat grafik, peta, diagram.

f. Aktivitas gerak (motor aktivities), yanng termasuk didalaamnya termasuk didalaamnya antara lain: melakukan percobaan membuat konstruksi, model mereprasi, bermain berkebun, berternak.

g. Aktivitas gerak (metal aktivities), sebagai contoh misalnya: menanggapi, mengingat, memecahkan soal, menganalisis, melihat hubungan, mengambil kepetusan.

h. Aktivitas emosional (emotional activities), seperti misalny, menaruh minat, merasa bosan, gembira, bersemangat, bergairah, berani, tenang, gugup.

\section{Prestasi Belajar}

Definisi prestasi belajar menurut Djamarah (1994), Penilaian pendidikan tentang kemajuan siswa dalaam segala hal yanng dipelajari di sekolah yanng menyanngkut pengetahuan atau kecakapan / keterampilan yanng dinyatakan sesudah hasil penilaian. Penilaian tersebut dilakukan melalui evaluasi. Sedangkan menurut Sudjana (1990), mengatakan bahwa prestasi belajar adala kemampuan yanng dimiliki setelah menerima pengalaman belajar.

Prestasi belajar merupakan gambaran dari keberhasilan sesuatu proses belajar mengajar secara keseluruhan. Dengn demikian prestasi merupakan perubahanperubahanyanng dicapai oleh seseorang. Perubahan-perubahan tersebut kemudian diukur dan dinilai yanng kemudian diwujudkan dalaam angka dan pernyataan.

Berdasarkan pengertian diatas dapat disimpulkan bahwa prestasi belajar yanng dimaksud dalaam hal ini adala hasil yanng dicapai oleh individu setelah yanng bersangkutan mengalami proses belajar atau diajarkan sesuatu pengetahuan tertentu.

Faktor yanng mempengaruhi prestasi belajar menurut Slameto (2003) dibagi menjadi dua bagian yaitu faktor internal dan faktor eksternal.

Banyak sekali pendekatan atau model pembelajaran yanng dapat digunakan untuk meningkatkan aktivitas dan prestasi belajar siswa, salah satunya yaitu melalui pendekatan CTL (Contextual Teaching and Learning) di dalaam proses belajar menngajar.

\section{Pendekatan Pembelajaran kontekstual (Contextual Teaching and Learning).}

Pembelajaran kontekstual adala konsep pembelajaran yanng membantu guru mengaitkan materi yanng diajarkan dengn situasi dunia nyata siswa. Mendorong 
siswa membuat hubungan antara pengetahuan yanng dimilikinya dengn penerapan dalaam kehidupan sehari-hari yanng melibatkan tujuh komponen utama pembelajaran yanng efektif yaitu: kontrukstivisme (constructivisme), bertanya (question), menemukan (inquiry), masyarakat belajar (learning community), pemodelan (modeling), refleksi (reflection) dan penelitian yanng sebenarnya (autenic assessment) (Trianto, 2008).

Pembelajaran kontekstual memfokuskan diri padaa banyak aspek dari tiap lingkungan pembelajaran. Teori ini mendorong pendidik untuk memilih atau merancang lingkungan belajar yanng menggabungkan sebanyak mungkin bentuk pengalaman sosial (sosial, budaya fisik, dan psikologi) untuk mencapai belajar yanng diinginkan dalaam lingkungan belajar semacam itu siswa akan mendapat hubungan bermakna antara ide dan penerapan praktis dalaam konteks dunia nyata (Depdiknas, 2002).

Ada tujuh komponen pembelajaran kontekstual yaitu (Trianto, 2008)

a. Kontrukstivisme (contrukstivisme)

Merupakan landasan filosofi pembelajaran kontekstual yaitu bahwa pengetahuan yanng dibangun oleh manusia sedikit hasilnya diperluas melalui konteks yanng terbatas atau kaidah yanng siap untuk diambil atau diingat. Manusia harus mengontruksikan pengetahuan itu dan memecahkan masalah dan menemukan sesesuatu yanng berguna bagi dirinya sendiri. Landasan berfikir kontruktivisme agak berbeda, dengn pandangan model ini bisa berupa cara mengekspresikan sesesuatu, cara melafalkan bahasa atau guru yanng memberikan contoh cara mengerjakan sesesuatu.

b. Menemukan (inquiry)

Adala cara berfikir tentang apa yanng baru dipelajarai atau belajar kebelakangan tentang apa-apa yanng sudah kita harapkan bukan hasil mengingat seperangkat fakta-fakta, tetapi hasil dari menemukan sendiri. Guru harus merancang kegiatan yanng merujuk padaa kegiatan yanng menemukan apapun materi yanng diajarkan.

c. Bertanya (question)

Merupakan strategi utama pembelajaran yanng berbasis kontekstual. Bertanya dalaam pandangan pembelajaran dipandang sebagai kegiatan guru untuk mendorong, membimbing dan menilai kemampuan berfikir siswa. Bagi siswa kegiatan bertanya merupakan bagian penting dalaam melaksanakan pembelajaran yanng berbasis inquiry, yaitu menggali informasi, mengkonfirmasi apa yanng diketahui dan mengarahkan perhatian padaa aspek yanng belum diketahui.

d. Masyarakat belajar (Learning Community)

Merupakan hasil pembelajaran yanng diperoleh dari kerja sama dengn orang lain. Dalaam kelas pembelajaran kontekstual, guru disarankan membagi siswa dalaam kelompok-kelompok yanng anggotanya heterogen. Yanng bertujuan agar antara siswa yanng satu dengn siswa yanng lainnya dapat menyelesaikan permasalahan belajarnya dengn cara bersama.

e. Pemodelan (modelling)

Pemodelan maksudnya dalaam sebuah pembelajaran keterampilan atau pengetahuan tertentu, ada model yanng bisa ditiru. Model ini berupa cara 
mengekspresikan sesesuatu, cara melafalkan bahsa Inggris atau guru yanng memberikan contoh cara mengerjakan sesesuatu.

f. Refleksi (reflection)

Pembelajaran dengn pendekatan refleksi adala cara berfikir tentang apa yanng baru dipelajari atau berfikir kebelakang tentang apa-apa yanng sudah kita lakukan dimasa yanng lalu. Refleksi merupakan respon terhadap kejadian, aktifitas atau pengetahuan yanng baru diterima realisasi dapat berupa pernyataan langsung tentang apa yanng diperolehnya hari itu, catatan jurnal dibuku siswa, hasil karya, kesan dan saran siswa mengenai pembelajaran hari itu.

g. Penilaian Sebenarnya (authentic assessment)

Yaitu proses pengumpulan berbagai data yanng bisa memberikan gambaran perkembangan belajar siswa perlu diketahui oleh guru agar bisa memastikan bahwa siswa mengalami proses pembelajaran yanng benar.

Menurut Blancahar (2001) bahwa strategi pembelajaran yanng berasosiasi dengn pembelajaran kontekstual yaitu :

a. Problem-based learning, yaitu sesuatu pendekatan pembelajaran yanng menggunakan masalah dunia nyata sebagai konteks bagi siswa untuk belajar berfikir kritis dan keterampilan pemecahan masalah dalaam rangka memperoleh pengetahuan dan konsep penting dari materi pembelajaran.

b. Autentic instruction, yaitu pendekatan pengajaran yanng memperkenankan siswa mempelajari konteks yanng bermana melalui pengembangan keterampilan baru, kemudian diwujudkan ke dalaam prodek nyata.

c. Inquiry-based learning, yaitu pendekatan pembelajaran yanng mengikuti metodologi sains dan memberikan untuk belajar bermakna.

d. Project-based learning, yaitu pendekatan pembelajaran yanng memperkenankan siswa untuk bekerja mandiri dalaam membangun pembelajarannya (pengetahuan dan keterampilan baru) yanng diwujudkan dalaam produk nyata.

e. Worka-based learning, yaitu pendekatan pembelajaran yanng memungkinkan siswa menggunakan tempat bekerja untuk mempelajari materi ajar dan mengunakan kembali ketempat bekerja.

f. Service Learning, yaitu pendekatan pembelajaran yanng manjanjikan sesuatu penerapan praktis dari pengetahuan baru dan berbagi keterampilan untuk memenuhi kebutuhan masyarakat melalui proyek atau tugas terstruktur dan kegiatan lainnya.

Pendekatan CTL (Contextual Teaching and Learning) dapat diterapkan ke dalaam berbagai macam pokok bahasan seperti Segitiga, usaha dan energi, Gerak lurus, Besaran dan satuan dan sebagainya. Dalaam penelitian ini peneliti ingin menerapkan pendekatan CTL (Contextual Teaching and Learning) ke dalaam pokok bahasan segitiga di kelas VIIa SMP Negeri 2 Bolo Tahun Pelajaaran 2019/2020.

\section{METODE PENELITIAN}

\section{Jenis Penelitian}

Adapun jenis penelitian yanng digunakan adala penelitian tindakan kelas (PTK). Penelitian tindakan kelas merupakan penelitian yanng dilakukan oleh guru di 
kelas atau di sekolah tempat ia mengajar dengn menekankan padaa penyempurnaan atau peningkatan proses dan praktik pembelajaran (Arikunto, 2008).

\section{Pendekatan Penelitian}

Adapun pendekatan yanng digunakan dalaam penelitian ini adala pendekatan kualitatif dan pendekatan kuantitatif. Pendekatan kualitatif digunakan untuk mengolah data hasil observasi pelaksanaan pembelajaran, sedangkan pendekatan kuantitatif digunakan untuk mengolah data hasil belajar. (Sugiyono, 2010)

\section{Rancangan Penelitian}

Penelitian tindakan kelas ini direncanakan pelaksanaannya dalaam dua siklus, setiap siklus terdiri dari 4 tahapan yaitu: perencanaan, pelaksanaan tindakan, observasi dan evaluasi dan refleksi.

Adapun tahap masing-masing siklus adala sebagai berikut :

1. Siklus I

- Fase Perencanaan

Adapun kegiatan yanng dilakukan dalaam siklus untuk menerapkan "Kontekstual" maka peneliti dan guru mempersiapkan hal-hal sebagai berikut :

a. Menyusun rencana pelaksanaan pembelajaran.

b. Membuat lembar observasi untuk siswa dan guru

c. Menyiapkan lembar kerja siswa (LKS)

d. Mendisain alat evaluasi dan merencanakan analisis hasil tes

- Fase Pelaksanaan Tindakan

Pelaksanaan kegiatan yanng dilakukan padaa tahap ini adala melaksanakan skenario pembelajaran yanng telah dirancang.

- Fase Observasi dan evaluasi

Kegiatan observasi ini dilakukan secara kontinu setiap kali pembelajaran berlangsung untuk mengetahui kesesuaian skenario atau rencana pembelajaran dengn pelaksanaan pembelajaran. Sedangkan evaluasi dilakukan setelah akhir siklus dengn memberikan tes pilihan ganda yanng dikerjakan secara individual.

- Fase Refleksi

Padaa tahap ini, peneliti bersama guru yanng bertindak sebagai observer mengkaji hasil observasi dan hasil evaluasi yanng diperoleh. Dari hasil analisis tersebut peneliti dan observer mendiskripsikan berbagai kekurangan dalaam tahap pelaksanaan dan menganalisa penyebabnya serta mencari solusi perbaikannya untuk digunakan sebagai dasar merencanakan dan melaksanakan siklus berikutnya.

2. Siklus II

Siklus II dilakukan apabila pembelajaran padaa siklusI belum berhasil. Pelaksanaan siklus kedua sama dengn siklus pertama. Tindakan padaa siklus kedua ditentukan berdasarkan hasil refleksi padaa siklus pertama.

\section{Teknik Pengumpulan Data}

1. Jenis Data

@ 2020 DIKSI (https://jurnal.bimaberilmu.com/index.php/diksi) 
Jenis data yanng digunakan dalaam penelitian ini adala data kualitatif dan data kuantitatif. Data kualitatif diperoleh dari data hasil observasi pelaksanaan pembelajaran, sedangkan data kuantitatif diperoleh dari data hasil belajar.

2. Cara Pengambilan Data

Cara pengambilan data dalaam penelitian ini adala

1. Data hasil belajar dan ketuntasan belajar siswa diperoleh dengn cara memberikan tes evaluasi atau ulangan harian padaa siswa.

2. Data tentang aktivitas belajar mengajar diperoleh melalui lembar observasi.

\section{Instrumen Penelitian.}

Suharsimi A (2002) menerangkan, bahwa instrumen penelitian adala alat/fasilitas yanng digunakan oleh peneliti dalaam mengumpulkan data agar pekerjaan lebih mudah dan hasilnya lebih baik, dalaam arti lebih cermat, lengkap dan sistematis sehingga lebih mudah diolah. berikut ;

Adapun instrumen yanng digunakan dalaam penelitian ini adala sebagai

1. Lembaran Observasi

Lembar observasi merupakan alat pengamatan secara sistematis terhadap gejala yanng tampak padaa objek penelitian, obsevasi dilakukan untuk mengetahui kegiatan yanng dilakukan guru dan siswa selama proses pembelajaran.

2. Tes Hasil Belajar

Tes hasil belajar digunakan untuk mengetahui kemampuan siswa dalaam menerapkan pembelajaran CTL (Contextual Teaching and learning). Penyusunan tes dilakukan oleh peneliti, dan dibuat dalaam bentuk tes objektif dengn jumlah soal sebanyak 25 butir soal.

\section{Analisa Data}

Data hasil penelitian tindakan kelas ini dikumpulkan dan dianalisis dengn cara sebagai berikut :

1. Data Hasil Observasi

\section{a. Data Aktivitas Guru}

Adapun cara penilaian terhadap deskriptor aktivitas yanng dilakukan oleh guru dalaam proses pembelajaran adala sebagai berikut :

1) Ya : Diberikan jika aktivitas terhadap descriptor dilakukan oleh guru padaa saat pelaksanaan proses pembelajaran

2) Tidak : Diberikan jika aktivitas terhadap descriptor tidak dilakukan oleh guru padaa saat pelaksanaan proses pembelajaran.

Data aktivitas guru selama pembelajaran dianalisis dengn cara sebagai berikut :

1) Menentukan skor yanng diperoleh guru :

Skor 4 : jika 3 (semua) deskriptor nampak

Skor 3 : jika 2 descriptor nampak

Skor 2 : jika 1 descriptor nampak

Skor 1 : jika tidak ada descriptor yanng nampak

2) Menentukan MI (Mean Ideal) dan SDI (Standar Deviasi Ideal) 


$$
\begin{aligned}
& \text { MI }=\frac{1}{2}(\text { Skor Maksimal }+ \text { Skor Minimal }) \\
& \text { SDI }=\frac{1}{6}(\text { Skor Maksimal }- \text { Skor Minimal })
\end{aligned}
$$

3) Menentukan kriteria aktivitas guru

Kriteria aktivitas guru dapat dilihat dari tabel berikut ini :

Tabel 2. Pedoman kriteria aktivitas guru

\begin{tabular}{|c|c|}
\hline Interval & Kategori \\
\hline $\mathrm{Ag} \geq \mathrm{MI}+1,5 \mathrm{SDI}$ & Sangat Baik \\
\hline $\mathrm{MI}+0,5 \mathrm{SDI} \leq \mathrm{Ag}<\mathrm{MI}+1,5 \mathrm{SDI}$ & Baik \\
\hline $\mathrm{MI}-0,5 \mathrm{SDI} \leq \mathrm{Ag}<\mathrm{MI}+0,5 \mathrm{SDI}$ & Cukup Baik \\
\hline $\mathrm{MI}-0,5 \mathrm{SDI} \leq \mathrm{Ag}<\mathrm{MI}-1,5 \mathrm{SDI}$ & Kurang Baik \\
\hline $\mathrm{Ag}<\mathrm{MI}-1,5 \mathrm{SDI}$ & $\begin{array}{c}\text { Sangat Kurang } \\
\text { Baik }\end{array}$ \\
\hline
\end{tabular}

Diketahui :

Jumlah item : 7

Skor maksimal tiap item $: 4$

Skor minimal tiap item $\quad: 1$

Untuk menilai kategori aktivitas guru, ditentukan terlebih dahulu MI dan SDI dengn rumus sebagai berikut:

$\mathrm{MI}=\frac{1}{2} \mathrm{x}$ (skor maksi mum + skor minimum $)$

$$
\begin{aligned}
& =\frac{1}{2} \times(7 \times 4)+(7 \times 1) \\
& =17,5 \\
\text { SDI }=\frac{1}{6} & \times(\text { skor maksimum }- \text { skor minimum }) \\
& =\frac{1}{6} \times(7 \times 4)-(7 \times 1) \\
& =3,5
\end{aligned}
$$

Tabel 3. Pedoman interval nilai aktivitas Guru

\begin{tabular}{|c|c|}
\hline Interval nilai & Kategori \\
\hline $\mathrm{Ag} \geq 22,75$ & Sangat Baik \\
\hline $19,25 \leq \mathrm{Ag}<22,75$ & Baik \\
\hline $15,75 \leq \mathrm{Ag}<19,25$ & Cukup Baik \\
\hline $12,25 \leq \mathrm{Ag}<15,75$ & Kurang Baik \\
\hline $\mathrm{Ag}<12,25$ & Sangat Kurang Baik \\
\hline
\end{tabular}

b. Data Aktivitas Siswa

Penelitian terhadap aktivitas siswa dilakukan dengn menggunakan lembar observasi. Data yanng diperoleh kemudian dianalisis sebagai berikut

1) Menentukan skor aktivitas yanng diperoleh siswa dan cara menghitung skornya.

2. Data Tes Hasil Belajar 
Setelah memperoleh data hasil belajar, maka data tersebut dianalisis dengn mencari ketuntasan belajar, kemudian dianalisis secara kuantitatif.

a. Ketuntasan Individu

Setiap siswa dalaam proses belajar mengajar dikatakan tuntas apabila memperoleh nilai lebih atau sama dengn 65 (Arjuddin, 2004).

b. Ketuntasan Klasikal

Untuk mencari porsentase prestasi belajar setelah proses pembelajaran segitiga dengn pembelajaran CTL (Contextual Teaching and Learning) digunakan rumus porsentase sebagai berikut:

$$
P=\frac{X}{N} x 100 \%
$$

Keterangan :

$\mathrm{P}=$ Porsentase ketuntasan klasikal

$\mathrm{X}=$ Jumlah siswa yanng mendapat nilai $\geq 65$

$\mathrm{N}=$ Jumlah siswa

(Purwanto, 2004).

Patokan untuk menyatakan ketuntasan klasikal dalaam proses pembelajaran CTL (Contextual Teaching and Learning) adala minimal $85 \%$ yanng nilainya lebih $\geq 65$ (Arjuddin, 2004).

\section{HASIL DAN PEMBAHASAN}

\section{Hasil Penelitian}

Penelitian Tindakan Kelas ini dilakukan untuk mengetahui tingkat prestasi siswa padaa pokok materi segitiga siswa SMP Negeri 2 Bolo kecamatan Wanasaba melalui penerapan pembelajaran CTL. Penelitian ini dilaksanakan dalaam 2 (dua) siklus, dari hasil observasi diperoleh data kualitatif yanng memberikan gambaran tentang kegiatan yanng dilakukan oleh guru dan siswa selama proses belajar mengajar dan hasil tes yanng diperoleh berupa data kuantitatif. Data-data tesebut selanjutnya dianalisis dengn menggunakan metode yanng telah ditetapkan sebelumnya.

\section{Analisis Data Penelitian Siklus I}

\section{a. Data Prestasi Belajar}

Data prestasi belajar siswa siklus I adala membahas tentang segitiga dan jenis-jenis segitiga. Data prestasi belajar siswa siklus I dapat di lihat padaa tabel berikut ini.

\section{Tabel 4.1 Data Hasil Evaluasi Belajar Siklus I}

\begin{tabular}{|c|l|c|}
\hline No & \multicolumn{1}{|c|}{ Keterangan } & Hasil \\
\hline 1 & Nilai Tertinggi & 90 \\
2 & Nilai Terendah & 40 \\
3 & Rata-rata Nilai & 68,70 \\
4 & Jumlah siswa yanng mengikuti tes & 34 Orang \\
5 & Jumlah siswa yanng tuntas & 24 Orang \\
6 & Persentase siswa yanng tuntas & $70,58 \%$ \\
\hline
\end{tabular}


Dari tabel diatas dapat dilihat bahwa nilai rata-rata kelas adala 68,70 dari 34 orang yanng mengikuti tes, jumlah siswa yanng tuntas sebanyak 24 orang. Persentase ketuntasan belajar adala $70,58 \%$ dengn kategori daya serapnya baik, persentase ketuntasan yanng dicapai masih kurang dari standar ketuntasan klasikal 85\%. Jadi kesimpulannya bahwa padaa siklus I belum mencapai ketuntasan belajar secara klasikal.

\section{b. Data Observasi Aktivitas Siswa}

Berdasarkan data hasil pengamatan yanng dilakukan padaa kegiatan mengajar menggunakan pendekatan CTL padaa pokok materi segitiga di kelas VIIa semester I SMP Negeri 2 Bolo di peroleh data sebagai berikut:

1) Suasana kelas dalaam kegiatan belajar mengajar kurang kondusif

2) Kesiapan siswa dalaam menerima materi masih sangat kurang

3) Masih terlihat adanya siswa yanng kurang aktif dikarenakan kurangnya minat belajar

4) Siswa kurang tertib dalaam berdiskusi dan menyelesaikan soal-soal yanng ada, terlihat masih banyak yanng main-main dan berpindah-pindah tempat duduk.

5) Guru masih belum sempurna memberikan bimbingan padaa siswa atau individu saat pembelajaran berlangsung dengn menggunakan pendekatan CTL.

Aktivitas belajar siswa siklus I termasuk dalaam kategori cukup aktif sehingga aktivitas kelas di siklus I ini dikatakan cukup baik karena hasil analisis diperoleh aktivitas siswa dengn kualifikasi cukup aktif.

\section{c. Data Observasi Kegiatan Guru}

Jumlah yanng diamati adala 7 indikator, dimana setiap indikator terdiri dari 3 deskriptor. Setiap indikator perilaku guru padaa penilaian mengikuti aturan sebagai berikut:

BS (Baik Sekali) : skor 4 jika semua deskriptor yanng nampak

B (Baik) : skor 3 jika ada 2 deskriptor yanng nampak

$\mathrm{C}$ (Cukup) : skor 2 jika ada 1 deskriptor yanng nampak

C (Cukup) : :skor 1 jika tidak ada deskriptor yanng nampak

Ringkasan Data mengenai aktivitas Guru selama proses pembelajaran dengn menggunakan pendekatan pembelajaran CTL padaa siklus 1 dapat dilihat dibawah ini. Dimana skor maximum idealnya (MI) 17,5 dan standar deviasinya3,5.Aktivitas Guru padaa siklus 1 termasuk dalaam kategori cukup baik Maka kekurangan yanng terdapat padaa siklus I adala:

1) Komunikasi dua arah antara guru dan siswa masih kurang

2) Komunikasi dan kerja sama siswa dalaam kelompok nampak kurang. Demikian siswa yanng berkemampuan rendah, enggan bertanya padaa temannya yanng berkemampuan tinggi

3) Guru kurang membimbing siswa dalaam diskusi

4) Guru kurang mengatur alokasi waktu, sehingga waktu tidak cukup

5) Guru kurang memotivasi siswa dalaam membangkitkan minat padaa awal pelajaaran

Memperhatikan kekurangan diatas, maka rencana perbaikan yanng akan dilakukan padaa siklus II adala:

1) Guru hendaknya menekankan padaa siswa agar membaca dan mempelajari materi yanng telah diberikan, agar dalaam pelaksanaan pembelajaran 
selanjutnya dapat berjalan dengn lancar serta memberikan beberapa pertanyaan dan memberikan kesempatan kepadaa siswa untuk bertanya, sehingga komunikasi antara guru dan siswa tercipta

2) Guru menentukan tutor sebaya untuk tiap-tiap kelompok agar mau membantu atau mengajari temannya yanng belum bisa. Guru menekankan kepadaa siswa bahwa kelompok yanng dikatakan berhasil apabila tiap anggota kelompoknya mengerti atau bisa menjawab pertanyaan yanng diberikan

3) Guru lebih aktif memberikan bimbingan kepadaa tiap kelompok dengn terus mengoreksi kelompok padaa tiap pelajaaran berlangsung dengn lebih aktif dan sabar membimbing siswa yanng mengalami kesulitan

4) Guru mengatur kembali alokasi waktu serta menentukan jumlah dan tingkat kesulitan soal sesuai dengn waktu yanng tersedia

5) Guru memberikan motivasi kepadaa siswa untuk membangkitkan minat padaa pelajaaran yaitu dengn memberikan gambaran tentang kegunaan materi yanng sedang dipelajari dalaam kehidupan sehari-hari agar suasana kelas kelihatan hidup. Hal ini akan berpengaruh terhadap kesiapan dan konsentrasi siswa, sehingga perhatian siswa akan menjadi lebih terfokus

6) Guru supaya jangan terlalu cepat dalaam menjelaskan atau membahas soal-soal yanng ada dan hendaknya semua siswa dilibatkan untuk dapat membuat kesimpulan yanng akan dijadikan catatan atau rangkuman hasil kegiatan belajar mengajar padaa pertemuan berikutnya.

\section{Analisis Data Penelitian Siklus II}

\section{a. Data Prestasi Belajar}

Pelaksanaan pembelajaran padaa siklus II hampir sama dengn siklus I, namun padaa siklus II dilakukan perbaikan berdasarkan hasil refleksi siklus I. Padaa siklus II ini dilakukan pembelajaran untuk memperbaiki pembelajaran padaa siklus I. Data tentang prestasi belajar siswa padaa siklus II dapat dilihat padaa tabel:

Tabel 4.2 Data Hasil Evaluasi Belajar Siklus II

\begin{tabular}{|c|l|c|}
\hline No & \multicolumn{1}{|c|}{ Keterangan } & Hasil \\
\hline 1 & Nilai Tertinggi & 100 \\
2 & Nilai Terendah & 50 \\
3 & Rata-rata Nilai & 78,91 \\
4 & Jumlah siswa yanng mengikuti tes & 34 Orang \\
5 & Jumlah siswa yanng tuntas & 31 Orang \\
7 & Persentase siswa yanng & $92,17 \%$ \\
\hline
\end{tabular}

Dari tabel diatas dapat dilihat bahwa nilai rata-rata siswa adala 78,91. Dari jumlah seluruh siswa 38 orang yanng mengikuti tes adala sebanyak 34. Jumlah siswa yanng tuntas sebanyak 31 orang dengn kategori daya serapnya adala sangat baik. Persentasi ketuntasan belajar adala 92,17\%, sehingga persentasi ketuntasan klasikalnya tercapai, jadi kesimpulannya bahwa padaa siklus II sudah mencapai ketuntasan belajar secara klasikal.

\section{b. Data Observasi Aktivitas Siswa}

Data lengkap tentang aktivitas siswa selama pembelajaran dengn menggunakan pendekatan CTL padaa siklus II diperoleh data sebagai berikut:

1. Guru sudah banyak memberikan motivasi padaa saat membuka pelajaaran 
2. Suasana kelas dalaam kegiatan belajar mengajar sudah kelihatan hidup, serta guru lebih aktif membimbing siswa yanng mengalami kesulitan

Hasil analisis aktifitas belajar siswa selama proses pembelajaran dengn menggunakan pendekatan pembelajaran CTL padaa siklus II yaitu skor maximum idealnya (SMi) adala 16 dan standar deviasinya (SDi) adala 5,33. Aktivitas belajar siswa siklus II termasuk dalaam kategori aktif sehingga aktivitas kelas di siklus II ini dikatakan baik karena hasil analisis diperoleh aktivitas siswa dengn kualifikasi aktif.

\section{c. Data Observasi Kegiatan Guru}

Jumlah yanng diamati adala 7 indikator, dimana setiap indikator terdiri dari 3 deskriptor. Setiap indikator prilaku guru padaa penilaian mengikuti aturan sebagai berikut:

BS (Baik Sekali) : skor 4 jika semua deskriptor yanng nampak

B (Baik) : skor 3 jika ada 2 deskriptor yanng nampak

C (Cukup) : skor 2 jika ada 1 deskriptor yanng nampak

$\mathrm{C}$ (Cukup) : skor 1 jika tidak ada deskriptor yanng nampak

Dari tindakan siklus II ternyata target yanng ditetapkan oleh kurikulum sudah tercapai baik dari persentase ketuntasan dan aktivitas siswa, dengn demikian, siklus berikutnya tidak perlu dilakukan karena telah diperoleh informasi-informasi yanng cukup untuk mengambil beberapa keputusan sehubungan dengn target penelitian ini. Walaupun demikian masih ada beberapa siswa yanng masih dibawah target, maka perlu mendapat perhatian dan penanggulangan khusus dari guru bidang studi yanng bersangkutan.

\section{Pembahasan}

Penelitian tindakan kelas ini dilakukan sebagai upaya untuk meningkatkan prestasi belajar siswa padaa pokok materi segitiga kelas VIIA SMP Negeri 2 Bolo dengn menerapkan pembelajaran Kontekstual.

Penelitian ini dilaksanakan sesuai dengn prosedur Penelitian Tindakan Kelas (PTK) yanng telah ditetapkan dengn diawali dengn proses perencanaan, pelaksanan tindakan, observasi, sampai refleksi. Pelaksanaan tindakan dilaksanakan dalaam dua kali kegiatan pembelajaran menggunakan metode pembelajaran CTL padaa pokok materi Segitiga. Adapun langkah-langkah pembelajaran tertuang dalaam RPP (Rencana Pelaksanaan Pembelajaran). Selama proses pembelajaran berlangsung dilakukan observasi terhadap aktivitas siswa dan guru yanng dicatat padaa lembar observasi.

Hasil penelitian siklus I menunjukkan bahwa rentang nilai terendah dan tertinggi cukup jauh, karena ada siswa yanng memiliki kemampuan rendah. Nilai rata-rata ketuntasan klasikal sebesar 70,58\% sedangkan skor aktivitas siswa adala 17 dengn kategor cukup aktif, di ketahui bahwa ketuntasan belajar belum mencapai target seperti yanng diharapkan karena masih banyak siswa yanng mengalami kesulitan dalaam berdiskusi dan tidak aktif dalaam mengikuti pelajaaran sehingga persentase ketuntasan klasikal hanya mencapai 70,58\% yanng masih kurang dari target ketuntasan maximum yaitu $85 \%$, untuk itu dilakukan tindakan padaa siklus II dengn cara memperbaiki kekurangan-kekurangan dan kelemaham- kelemahan padaa siklus I.

Berdasarkan analisis data, pelaksanaan tindakan padaa siklus I menunjukan bahwa prestasi belajar siswa belum tuntas hal ini disebabkan: 
1. Komunikasi dua arah antara guru dan siswa masih kurang

2. Komunikasi dan kerja sama siswa dalaam kelompok kurang, demikian siswa yanng berkemampuan rendah, enggan bertanya padaa temannya yanng berkemampuan tinggi

3. Guru kurang membimbing siswa dalaam kegiatan diskusi

4. Guru kurang mengatur alokasi waktu, sehingga waktu tidak cukup

5. Guru kurang memotivasi siswa dalaam membangkitkan minat padaa awal pelajaaran

Untuk mengatasi masalah tersebut guru melakukan perbaikan-perbaikan dalaam pembelajaran dan meningkatkan hal-hal yanng masih dianggap kurang. Apa yanng telah dicapai baik dilihat dari prestasi belajar dan aktivitas siswa maupun dari segi aktifitas guru belum mencapai target yanng ditetapkan, maka perbaikanperbaikan yanng perlu dilakukan adala sebagai berikut:

1. Guru hendaknya menekankan padaa siswa agar membaca dan mempelajari materi yanng telah diberikan, agar dalaam pelaksanaan diskusi selanjutnya dapat berjalan dengn lancar serta memberikan beberapa pertanyaan dan memberikan kesempatan kepadaa siswa untuk bertanya, sehingga komunikasi antara guru dan siswa tercipta.

2. Guru menentukan tutor sebaya untuk tiap-tiap kelompok agar mau membantu atau mengajari temannya yanng belum bisa. Guru menekankan kepadaa siswa bahwa kelompok yanng dikatakan berhasil apabila tiap anggota kelompoknya mengerti atau bisa menjawab pertanyaan yanng diberikan.

3. Guru lebih aktif memberikan bimbingan kepadaa tiap kelompok dengn terus mengoreksi kelompok padaa tiap pelajaaran berlangsung dengn lebih aktif dan sabar membimbing siswa yanng mengalami kesulitan.

4. Guru mengatur kembali alokasi waktu serta menentukan jumlah dan tingkat kesulitan soal sesuai dengn waktu yanng tersedia.

5. Guru memberikan motivasi kepadaa siswa untuk membangkitkan minat padaa pelajaaran yaitu dengn memberikan gambaran tentang kegunaan materi yanng sedang dipelajari dalaam kehidupan sehari-hari agar suasana kelas kelihatan hidup. Hal ini akan berpengaruh terhadap kesiapan dan konsentrasi siswa, sehingga perhatian siswa akan menjadi lebih terfokus.

6. Guru supaya jangan terlalu cepat dalaam menjelaskan atau membahas soal-soal dan hendaknya semua siswa dilibatkan untuk dapat membuat kesimpulan yanng akan dijadikan catatan atau rangkuman hasil kegiatan pembelajaran padaa pertemuan berikutnya.

Berdasarkan kekurangan-kekurangan tersebut, maka dilakukan tindakan perbaikan baik untuk aktivitas guru maupun untuk aktivitas belajar siswa yanng akan dilakukan padaa siklus selanjutnya.

Setelah dilakukan perbaikan-perbaikan dari kelemahan-kelemahan padaa siklus I dapat diketahui bahwa persentase ketuntasan padaa siklus II mencapai ketuntasan klasikal yaitu 92,17\%, berdasarkan hasil analisa data padaa siklus II terdapat nilai rata-rata kelas sebesar 78,91.

Dari hasil yanng diperoleh pembelajaran dengn menggunakan pendekatan pembelajaran CTL dapat melibatkan siswa secara aktif dan meningkatkan aktifitas serta hasil belajar siswa, karena dalaam pembelajaran menggunakan pendekatan pembelajaran CTL siswa dapat saling membantu memahami pembelajaran dan 
memperbaik jawaban teman serta kegiatan lainnya dengn mencapai tujuan belajar bersama. Perubahan yanng terjadi padaa siswa adala siswa lebih aktif dalaam belajar, siswa lebih antusias dalaam mengikuti pelajaaran, siswa lebih aktif bertanya (terjadi interaksi/ komunikasi antara siswa dengn siswa, dan siswa dengn guru).

Terjadinya peningkatan ini disebabkan juga oleh model pembelajaran dengn menggunakan penerapan pembelajaran CTL dalaam pembelajaran matematika yanng memiliki peranan.

Metode ini juga dapat membantu guru untuk mengarahkan siswanya menemukan konsep-konsep baru, di samping itu juga penerapan pembelajaran CTL dapat mengembangkan keterampilan proses, serta dapat mengoptimalkan hasil belajar (Trianto, 2008)

Penerapan pembelajaran CTL (Contextual Teaching and Learning) dapat meningkatkan prestasi belajar siswa kelas VIIA SMP Negeri 2 Bolo. Hal ini disebabkan dengn menggunakan penerapan pembelajaran CTL siswa akan lebih aktif tergabung dalaam pembelajaran.

Tujuan utama dari PTK (Penelitian Tindakan Kelas) adala untuk meningkatkan atau memperbaiki praktek-praktek pendidikan dan pengajaran. Perbaikan ini dapat dilihat dari peningkatan prestasi belajar siswa.

Hasil penelitian yanng telah dilakukan, ternyata penerapan pembelajaran dengn menggunakan penerapan pembelajaran CTL dapat meningkatkan prestasi belajar siswa kelas VIIA SMP Negeri 2 Bolo kecamatan Bolo.

\section{KESIMPULAN}

Berdasarkan hasil penelitian dalaam pembahasan maka dapat disimpulkan bahwa: 1) Pembelajaran Berbasis Kontekstual padaa pokok materi segitiga dapat meningkatkan aktivitas di Kelas VII SMP Negeri 2 Bolo Tahun 2019/2020. Hal ini dapat dilihat padaa aktivitas siswa siklus I berkategori cukup aktif dan siklus II berkategori aktif; 2) Pembelajaran Berbasis Kontekstual padaa pokok materi segitiga dapat meningkatkan aktivitas di Kelas VII SMP Negeri 2 Bolo Tahun 2019/2020. Hal ini dapat dari siklus I dengn porsentase ketuntasan belajar 70,58 \% ke siklus II dengn porsentase ketuntasan belajar 92,17\%. Peningkatan ini dikarenakan penerapan pembelajaran contextual teacing and learning (CTL) dapat membuat proses lebih jelas dan menarik sehingga membantu siswa lebih mudah memahami pelajaaran.

Saran dan tindak lanjut dari hasil penelitian ini adala 1) Dalaam proses belajar mengajar hendaknya menggunakan metode sesuai dengn materi yanng akan disampaikan agar siswa tidak cepat merasa bosan dalaam mengikuti pelajaaran; 2) Hasil penelitian ini diharapkan dapat digunakan sebagai bahan pertimbangan bagi guru dalaam upaya meningkatkan prestasi belajar siswa, khususnya padaa mata palajaran matematika; 3) Perlu dilakukan penelitian lebih lanjut mengenai pendekatan CTL padaa pokok bahasan yanng lain.

\section{DAFTAR PUSTAKA}

Arikunto, Suharsimi. (2002). Prosedur Penelitian Sesuatu Pendekatan Praktek. Jakarta: Rineka Cipta. 
Arikunto, Suharsimi. (2006). Penelitian Tindakan Kelas. Jakarta: Bumi Aksara.

Arikunto, Suharsimi. (2009). Dasar-Dasar Evaluasi Pendidikan Edisi Revisi. Jakarta: PT Bumi Aksara.

Aqib, Zainal. (2003). Profesional Guru Dalaam Pembelajaran. Jakarta : Insan Cendikia.

Aqib, Zainal. (2008). Penelitian Tindakan Kelas. Bandung: Yrama widya.

Blancahar. (2001). Strategi Pembelajaran Kontekstual. Jakarta : Rineka Cipta.

Depdiknas. (2002). Pendekatan Kontekstual (CTL). Jakarta: Depdiknas Dirjen Dikdasmen.

Depdiknas RI. (2003). Undang-Undang No 20 Tahun 2003 Tentang Sistem Pendidikan Nasional. Departemen Pendidikan Nasional Republik Indonesia Jakarta.

Depdiknas. (2004). Kurikulum 2004 Standar Kompetensi Mata Pelajaaran Sains SMP dan MTs. Jakarta.

Djamarah. (1994). Prestasi Belajar dan Kompetensi Guru. Surabaya : Usaha Nasional.

Djamarah. (2002). Psikologi Belajar. Jakarta : Rineka Cipta.

Hamalik,Oemar. (2005). Proses Belajar Mengajar. Bandung : Bumi Aksara.

Krisno. (2008). Ilmu Pengetahuan Alam SMP / MTs. Jakarta: Pusat Perbukaan, Departemen.

Muhibbin. (2001). Psikologi Belajar. Bandung. PT Remaja Rosdakarya.

Mulyasa. (2004). Kurikulum Berbasis Kompetensi. Bandung: Remaja Rosdarkarya.

Muslihatun. (2002). Pembelajaran Kontekstual. Jakarta: Depdiknas.

Nurhadi. (2002). Pembelajaran Kontekstual dan Penerapannya. Malang: Universitas Negeri Malang.

Nurkencana. (1999). Evaluasi Hasil Belajar. Usaha Nasional.

Purwanto. (2009). Evaluasi Hasil Belajar. Jakarta: PT Pustaka Belajar.

Prasodjo. (2003). Teori dan Aflikasi Fisika. Bandung: Yudistira.

Sahdin. (1996). Pendekatan Kontekstual. Dirjen Pendidikan Dasar dan Menengah.

Shen. (2003). Sosialisasi Pembelajaran Kontekstual Sebagai Sarana Pembelajaran Pengembangan KBK. Mataram: Infrastruktur LBA BMB.

Slameto. (2003). Belajar dan Faktor - Faktor Yanng Mempengaruhinya. Jakarta: Bina Aksara.

Sugiyono. (2010). Metode Penelitian Kuantitatif Kualitatif. Bandung: Alfabeta Zain. (2002). Belajar dan Pembelajaran. Jakarta: PT. Rineka Cipta. 